\title{
Pengaruh E-Learning Berbantuan Google Classroom Terhadap Kemampuan Pemecahan Masalah Matematis
}

\author{
Sudarman $^{1}$, Sartika $^{2}$, Iip Sugiharta ${ }^{3}$, Farida $^{4}$, \\ 1,2,3,4 Program Studi Pendidikan Matematika, Fakultas Tarbiyah dan Keguruan, Universitas Islam Negeri Raden Intan Lampung, \\ Jl. Letnal Kolonel H. J1 Endro Suratmin Sukarame, kec. Sukarame, Kota Bandar Lampung, Indonesia \\ husnisartika54@gmail.com
}

\begin{abstract}
E-learning is a learning system that utilizes information and communication technology such as google classroom. Based on preliminary studies, mathematical problem solving is still low because educator-centered learning makes it saturated so that the material provided is difficult to understand and, educators are not familiar with the distance learning system. The purpose of this study was to determine the effect of E-learning learning on the mathematical problem-solving abilities of seventh grade students of SMP Al-Huda Jati Agung using a quasi-experimental design method. The population of this research is students of class VII using the Cluster Random Sampling technique obtained the sample, namely class VII A of the experimental class with E-learning learning and class VII B of the conventional learning control class. The data collection technique used is in the form of test questions. The results of data analysis showed the effect of E-learning learning assisted by Google classroom on students' mathematical problem-solving abilities because it made it easier for students to innovate in finding learning resources, not only on educators. So, it is concluded that there is an effect of E-learning learning on mathematical problem-solving abilities.
\end{abstract}

Keywords: E-learning, Problem-Solving

\begin{abstract}
Abstrak
E-learning merupakan sistem pembelajaran yang memanfaatkan teknologi informasi dan komunikasi seperti google classroom. Berdasarkan studi pendahuluan pemecahan masalah matematis masih rendah karena pembelajaran berpusat pada pendidik membuat jenuh sehingga materi yang diberikan sulit dipahami dan, tenaga pendidik belum terbiasa dengan sistem pembelajaran jarak jauh. Tujuan penelitian ini untuk mengetahui pengaruh pembelajaran $E$ learning terhadap kemampuan pemecahan masalah matematis peserta didik kelas VII SMP Al-Huda Jati Agung dengan metode quasi eksperimen desain. Populasi penelitian ini peserta didik kelas VII dengan menggunakan teknik Cluster Random Sampling didapat sampelnya yaitu kelas VIII A kelas eksperimen dengan pembelajaran E-learning dan kelas VIII B kelas kontrol pembelajaran konvensional.Teknik pengumpulan data yang digunakan berupa soal tes. Hasil analisis data terdapat pengaruh pembelajaran E-learning berbantuan google classroom terhadap kemampuan pemecahan masalah matematis peserta didik karena memudahkan peserta didik berinovasi mencari sumber belajar tidak hanya terpaku pada pendidik. Maka disimpulkan terdapat pengaruh pembelajaran E-learning terhadap kemampuan pemecahan masalah matematis.
\end{abstract}

Kata kunci: E-learning, Pemecahan Masalah Matematis

Copyright (c) 2021 Sudarman, Sartika, Iip Sugiharta, Farida

$\triangle$ Corresponding author: Sartika

Email Address: husnisartika54@gmail.com (Jalan Endro Suratmin-Sukarame, Bandar Lampung)

Received 07 July 2021, Accepted 28 July 2021, Published 02 August 2021

\section{PENDAHULUAN}

Perkembangan dan pemanfaatan teknologi secara optimal dapat menunjang proses pembelajaran.(Hubers et al., 2020) Teknologi dan informasi memiliki peranan penting di era pandemi Covid 19 terlebih Indonesia menggunakan sistem pembelajaran jarak jauh.(Dian et al., 2020) Beberapa daerah terpencil pada negara berkembang dinilai belum mampu menyediakan fasilitas teknologi untuk menunjang proses pemebelajaran.(Zhang et al., n.d.) Pandemi Covid 19 telah mengubah proses pemebelajaran secara langsung menjadi pembelajaran jarak jauh, maka diperlukan kesadaran pendidik dalam mengembangkan ilmu pengetahuan dan teknologi(Aji \& Fatma, 2020). Pembelajaran jarak jauh akan terlaksana dengan baik apabila terjalin kerjasama antara pendidik, peserta didik dan orang tua. 
Lembaga pendidikan dunia termasuk Indonesia, saat ini banyak menghentikan proses belajar tatap muka sebagai upaya memutus rantai penyebaran virus covid 19. Masalah tersebut menjadi tanggung jawab semua kalangan pendidikan, khususnya negara untuk memberikan fasilitas kepada seluruh steakholders dalam penerapan pemebelajaran jarak jauh. Rumusan rencana, persiapan dan solusi pemulihan pandemi covid 19 harus segera dibenahi untuk menekan kerugian dalam dunia pendidikan di masa mendatang(Onyema et al., 2020).

Pengembangan teknologi harus menjadi fokus penting pendidikan masa depan dalam mengembangkan pemebelajaran formal.(Ratheeswari, 2018) Melihat perkembangan dunia pendidikan yang harus diiringi dengan pengembangan metode dan media pembeljaran. Teknologi dapat membantu pendidik meningkatkan kemampuan menyampaikan pembelajaran secara menarik pada semua tingkatan pendidikan(Surani, 2019).

Pembelajaran E-learning mampu memberikan ruang dan kesempatan belajar peserta didik menjadi lebih fleksibel.(Aldiab et al., 2017) Dengan proses pembelajaran yang fleksibel mengubah konsep pembelajaran menjadi tidak hanya berpusat pada pendidik, sehingga mampu membuat peserta didik mencari sumber belajar lainnya. Pembelajaran E-learning juga mampu meningkatkan intensitas komunikasi antar peserta didik.(Ambara, 2020) Pembelajaran E-learning juga menyusun materi pemebelajaran secara terstruktur dalam satu media, seperti pada google classroom. Google classroom sebagai media pembelajaran menyediakan filtur lengkap dan mudah digunakan.

Proses pembelajaran diharapkan mampu mentransfer dan menerapkan materi pembelajaran yang telah dipelajari untuk memecahkan masalah(Permata et al., 2018). Kemampuan pemecahan masalah mstematis merupakan kemampuan yang harus dikembangkan dalam menghadapi perkembangan zaman. Sebagaian peserta didik belum mampu mengidentifikasi masalah dan menentukan tujuan proses pembelajaran(Murdiana, 2015).

Pada penilaian Programme For International Student Assesment (PISA), dari tahun 2000 hingga tahun 2012 peserta didik di Indonesia belum memperoleh hasil belajar yang memuaskan. Berikut table penilaian PISA pada literasi matematika(Kertayasa, 2015).

Tabel 1. Data Hasil Penilaian PISA Pada Literasi Matematika

\begin{tabular}{|c|c|c|}
\hline Tahun & $\begin{array}{c}\text { Negara Yang } \\
\text { Berpartisipasi }\end{array}$ & Peringkat Indonesia \\
\hline 2000 & 43 & 39 \\
\hline 2003 & 41 & 38 \\
\hline 2006 & 57 & 50 \\
\hline 2009 & 65 & 61 \\
\hline 2012 & 65 & 64 \\
\hline
\end{tabular}

Berdasarkan tabel hasil penilaian PISA pada literasi matematika menunjukkan bahwa sejak tahun 2000 hingga tahun 2012 Indonesia masih menjadi bagian dari peringkat terakhir dari jumlah negara yang 
Pengaruh E-Learning Berbantuan Google Classroom Terhadap Kemampuan Pemecahan Masalah Matematis, Sudarman Sartika, Iip Sugiharta, Farida

berpartisipasi. Kemampuan pemecahan masalah matematis menjadi kemampuan yang sangat dibutuhkan untuk menjawab perkembangan zaman(Santos et al., 2015). Proses pembelajaran diharapkan tidak hanya sebagai proses mentransfer ilmu pengetahuan, tetapi dapat menerapkan pengetahuan yang telah diterima untuk memecahkan masalah. Sebegaian peserta didik belum mampu mengidentifikasi masalah dan menetukan tujuan proses pembelajaran(Sahrudin, 2014).

Pada penelitian ini peneliti membatasi masalah yakni membahas E-learning berbantuan google classroom terhadap kemampuan pemecahan masalah matematis, dengan tujuan untuk mengetahui pengaruh E-learning berbantuan google classroom terhadap kemampuan pemecahan masalah matematis.

\section{METODE}

Penelitian ini dilakukan di SMP Al-Huda Jati Agung, Kabupaten Lampung Selatan, Provinsi Lampung. Metode penelitian ini meggunakan pendekatan kuantutatif dengan desain penelitian Quasy Eksperimen Design. Populasi penelitian ini seluruh siswa kelas VII di SMP Al-Huda Jati Agung yang berjumlah 5 kelas dengan pengambilan sampel menggunakan metode Cluster Random Sampling, sehingga terpilih kelas VII A sebagai kelas Eksperimen yang menerapkan pembelajaran E-learning dan kelas VII B sebagai kelas kontrol dengan menerapkan pembelajaran langsung, kemudian diberi soal tes kemampuan pemecahan masalah matematis menggunakan indikator dari komponen aspek kemampuan pemecahan masalah matematis yang dikemukakan oleh Polya (2014) yaitu: (1) memahami masalah, (2) membuat rencana (3) melaksanakan rencana, (4) meriksa kembali(Hadi \& Radiyatul, 2014).

Penelitian ini melewati prosedur sebagai berikut : 1). Membuat soal tes kemampuan pemecahan masalah matematis berdasarkan indikator yang digunakan dengan melalui uji validasi oleh ahli materi, 2). Melakukan uji isnturmen soal tes kemampuan pemecahan masalah matematis diluar populasi penelitian, 3). Menerapkan pembelajaran E-learning pada kelas eksperimen dan pemebelajaran langsung pada kelas kontrol, 4). Melakukan perhitungan hasil analisis data peneltian, 5). Menyimpulkan hasil penelitian

Instrumen penelitian ini terdiri dari tes berupa soal tes kemampuan pemecahan masalah matematis sebagai alat ukur untuk mengetahui kemampuan pemecahan masalah peserta didik dan non tes berupa dokumentasi pengamatan perilaku peserta didik serta alata bantu untuk mendokumentasikan proses penelitian. Analsis data peneltian ini menggunakan uji prasyarat dengan uji normalitas, uji homogenitas dan uji hipotesis menggunakan uji ANOVA dengan SPSS.

\section{HASIL DAN DISKUSI}

Penelitian ini dilakukan pada kelas VII A berjumlah 28 peserta didik sebagai kelas eksperimen dengan menerapkan pembelajaran E-learning dan kelas VII B berjumlah 28 peserta didik sebagai kelas kontrol dengan menggunakan pembelajaran langsung. Analisis data hasil penelitian dilakukan berdasarkan berdasarkan perolehan hasil nilai tertinggi $\left(\mathrm{X}_{m a k s}\right)$, nilai terendah $\left(\mathrm{X}_{\min }\right)$, medin, modus, jangkauan, simpangan baku (S) pada kelas eksperimen maupun kelas kontrol. Berikut rangkuman hasil data amatan nilai kemampuan pemecahan masalah matematis. 
Tabel 2. Deskripsi Data Amatan Kemampuan Pemecahan Masalah Matematis

\begin{tabular}{|c|c|c|c|c|c|c|c|}
\hline \multirow{2}{*}{ Kelompok } & \multirow{2}{*}{$\left(\mathbf{X}_{\text {maks }}\right)$} & \multirow{2}{*}{$\left(\mathbf{X}_{\text {min }}\right)$} & \multicolumn{4}{|c|}{$\begin{array}{c}\text { Ukuran Tendensi } \\
\text { Sentral }\end{array}$} & \multicolumn{2}{c|}{ Ukuran Dispresi } \\
\cline { 4 - 8 } & & & $\boldsymbol{X}$ & $\boldsymbol{M}_{\boldsymbol{e}}$ & $\boldsymbol{M}_{\mathbf{O}}$ & $\mathbf{R}$ & $\mathbf{S}$ \\
\hline Eksperimen & 100 & 61 & 85,516 & 89 & 83 & 39 & 11,107 \\
\hline Kontrol & 94 & 44 & 68,651 & 67 & 78 & 50 & 15,168 \\
\hline
\end{tabular}

Berdasarkan tabel deskripsi data amatan kemampuan pemecahan masalah matematis peserta didik pada kelas eksperimen lebih baik dibandingkan dengan kelas kontrol dilihat berdasarkan nilai maksimal, nilai minimal dan ukuran tedensi sentral. Uji prasyarat data amatan terdiri dari uji normalitas dan uji homogenitas. Uji normalitas harus dilakukan untuk mengetahui apakah data berdistribusi normal atau tidak. Uji nomalitas menggunakan metode Liliefors terhadap kemampuan pemecahan masalah matematis dan berpikir kreatif peserta didik. Berikut rangkuman hasil perhitungan uji normalitas kemampuan pemecahan masalah matematis peserta didik yang terdapat pada tabel berikut ini:

Tabel 3. Rangkuman Uji Normalitas

\begin{tabular}{|c|c|l|c|c|c|}
\hline No. & Kelas & Kemampuan & $\boldsymbol{L}_{\text {hitung }}$ & $\boldsymbol{L}_{\text {tabel }}$ & Keterangan \\
\hline 1 & Eksperimen & $\begin{array}{l}\text { Pemecahan masalah } \\
\text { Matematis }\end{array}$ & 0,115 & 0,164 & $H_{0}$ diterima \\
\hline 2 & Kontrol & $\begin{array}{l}\text { Pemecahan Masalah } \\
\text { Matematis }\end{array}$ & 0,119 & 0,164 & $H_{0}$ diterima \\
\hline
\end{tabular}

Berdasarkan rangkuman uji normalitas dengan taraf signifikansi 5\% dan dan $L_{\text {hitung }}$ untuk setiap kelas dan kemampuan memiliki nilai kurang dari $L_{\text {tabel }}(0,05)$, sehingga $H_{0}$ dapat diterima. Dapat disimpulkan bahwa data dari setiap kelompok berdistribusi normal. Uji homogenitas dilaukan untuk mengetahui beberapa variansi popuasi sama atau berbeda menggunakan uji Bartlett, dengan rangkuman hasil pada tabel berikut ini:

Tabel 4. Uji Homogenitas

\begin{tabular}{|c|l|c|c|c|}
\hline No & \multicolumn{1}{|c|}{ Sumber } & $\boldsymbol{X}^{\mathbf{2}}$ hitung & $\boldsymbol{X}^{\mathbf{2}}$ tabel & Keterangan \\
\hline 1 & $\begin{array}{l}\text { Kemampuan Pemecahan Masalah } \\
\text { Matematis }\end{array}$ & 2,579 & 3,481 & $H_{0}$ diterima \\
\hline
\end{tabular}

Berdasarkan tabel uji homogenitas dengan menggunakan taraf signifikansi 5\% untuk setiap $X^{2}$ hitung pada setiap kemampuan dengan hasil memiliki nilai kurang dari $X^{2}$ tabel, sehingga $H_{0}$ diterima dan dapat disimpulkan bahwa sampel berasal dari populasi yang homogen. Uji hipotesis penelitian dilakukan setelah mengetahui bahwa data berdistribusi normal dan berasal dari populasi yang homogen untuk diuji menggunakan uji ANOVA dengan SPSS, untuk hipotesis 1 dan 2 dapat dilihat pada tabel berikut: 
Pengaruh E-Learning Berbantuan Google Classroom Terhadap Kemampuan Pemecahan Masalah Matematis, Sudarman,

Tabel 5. Uji Hipotesis data ANOVA

\begin{tabular}{|l|r|r|r|r|r|}
\hline \multicolumn{7}{|c|}{ Tests of Between-Subjects Effects } \\
\hline Dependent Variable: KPMM & \multicolumn{1}{c|}{} \\
\hline Source & $\begin{array}{c}\text { Type III Sum } \\
\text { of Squares }\end{array}$ & Df & Mean Square & \multicolumn{1}{c|}{ F } & \multicolumn{1}{c|}{ Sig. } \\
\hline Corrected Model & $3844,571^{\mathrm{a}}$ & 1 & 3844,571 & 21,759 &, 000 \\
\hline Intercept & 332332,071 & 1 & 332332,071 & 1880,857 &, 000 \\
\hline Kelas & 3844,571 & 1 & 3844,571 & 21,759 &, 000 \\
\hline Error & 9541,357 & 54 & 176,692 & & \\
\hline Total & 345718,000 & 56 & & & \\
\hline Corrected Total & 13385,929 & 55 & & & \\
\hline
\end{tabular}

a. $\mathrm{R}$ Squared $=, 287$ (Adjusted R Squared $=, 274$ )

Berdasarkan uji hipotesis yang telah dilakukan, maka disimpulkan bahwa nilai $p$-value dalam kemampuan pemecahan masalah matematis $(\mathrm{KPMM})=0,000$ dan nilai $\propto$ kriteria $\mathrm{uji}=0,05$ yang berarti nilai $p$-value lebih kecil dibandingkan $\alpha$ kriteria uji, sehingga $H_{0 A}$ ditolak dengan demikian dapat disimpulkan bahwa terdapat pengaruh antara model pembelajaran E-learning terhadap kemampuan pemecahan masalah matematis.

Penelitian ini terdapat variabel bebas yaitu model pembelajaran E-learning dan variabel terikat kemampuan pemecahan masalah matematis. Populasi penelitian ini seluruh peserta didik kelas VII SMP Al-Huda Jati Agung dengan menggunakan Cluster Random Sampling terpilih kelas VII A sejumlah 28 peserta didik sebagai kelas eksperimen dengan pembelajaran E-learning dan kelas VII B sejumlah 28 peserta didik sebagai kelas kontrol dengan pembelajaran langsung.

Penelitian ini dilakukan pada materi himpunan untuk mengetahui pengaruh pembelajaran E-learning terhadap kemampuan pemecahan masalah matematis peserta didik. Untuk mengumpulkan data hipotesis peneliti memberikan materi himpunan kepada peserta didik di kelas eksperimen dan kelas kontrol. Untuk menguji kemampuan pemecahan masalah matematis, peneliti mengambil 3 dari 4 soal postest yang sebelumnya sudah dilakukan uji coba validitas, reliabilitas, tingkat kesukaran, dan daya beda.

Pembelajaran E-learning diawali dengan tahapan persiapan untuk menyiapkan peserta didik sebelum proses pembelajaran berlangsung.(Al-Ihwanah, 2016) Pendidik menyampaikan judul materi pembelajaran yang akan disampaikan dan memberikan movitasi dan apresiasi kepada peserta didik sebelum pembelajaran berlangsung. Tujuan pembelajaran juga disampikan pendidik kepada peserta didik sebelum membagikan materi pada kolom materi di Google Clasroom. Peserta didik dapat log in dengan cara mendownload aplikasi google classroom lalu memasukkan kode kelas yang telah diberikan pendidik seperti halnya gambar 1 (Pappas, 2015).

Pendidik dapat membuka kolom komentar sebagai ruang peserta didik untuk saling berdiskusi materi yang telah diberikan oleh pendidik, memberikan waktu kepada peserta didik untuk saling bertanya jawab pada kolom komentar yang telah disediakan. Peserta didik saling berdiskusi membahas materi yang telah diberikan untuk kemudian ditanggapi pendidik apabila terdapat persoalan yang tidak dapat dipecahkan oleh 
peserta didik melalui diskusi bersama di kolom komentar. Terdapat filtur download untuk mempermudah peserta didik mengakses materi yang telah disampaikan.

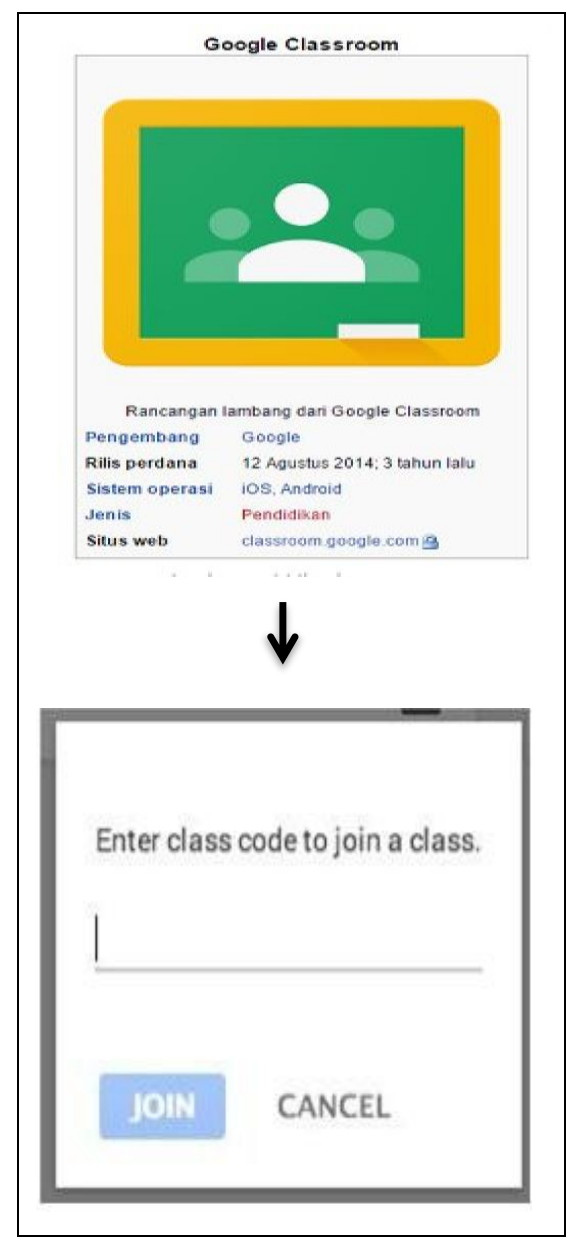

Gambar 1. Cuplikan Tampilan Login Google Classroom

Tahap selanjutnya yakni pelatihan, dengan cara membagikan tugas pada kolom tugas untuk kemudian dikerjakan masing-masing peserta didik lalu dikumpulkan pada kolom tugas. Pada google classroom juga terdapat filtur nilai, sehingga memudahkan pendidik untuk melakukan penilaian terhadap kinerja peserta didik secara efektif dan efesien.

Pembelajaran e-learning memudahkan peserta didik untuk mengakses materi secara fleksibel(Mailizar et al., 2020). Materi yang diterima peserta didik dapat terarsipkan dengan sistematis dan dapat kembali diakses, sehingga mengurangi hilangnya materi pembelajaran yang telah disampaikan pendidik. Peserta didik memiliki kesempatan mengulang materi pembelajaran yang telah disampaikan dengan berinovasi mencari sumber belajar lainnya yang tidak hanya bersumber dari pendidik.

Proses pembelajaran langsung pada kelas kontrol dimulai dengan penyampaian apresiasi, motivasi dan tujuan pembelajaran oleh pendidik. Pendidik memberikan materi himpunan secara langsung kepada peserta didik dengan metode ceramah dan tanya jawab, untuk kemudian diberikan tugas atau persoalan matematis yang akan diselesaikan oleh peserta didik. Proses penyelesaian masalah yang dilakukan peserta 
Pengaruh E-Learning Berbantuan Google Classroom Terhadap Kemampuan Pemecahan Masalah Matematis, Sudarman,

didik dilakukan secra individu dan kemudian dikumpulkan langsung kepada pendidik untuk diberi penilaian. Proses pembelajaran langsung membuat suasana kelas menjadi monoton karena pembelajaran yang hanya berpusat pada pendidik dan hanya sedikit peserta didik yang berani bertanya apabila terdapat materi yang belum dipahami.

Berdasarkan hal diatas disimpulkan bahwa terdapat pengaruh model pembelajaran E-learning terhadap kemampuan pemecahan masalah matematis peserta didik. Hal ini dapat terlihat dari hasil belajar pada kelas ekspermen yang menerapkan pembelajaran E-learning dan pada kelas kontrol yang menerapkan pemebelajaran langsung.

\section{KESIMPULAN}

Berdasarkan hasil penelitian yang telah dilakukan dapat disimpulkan bahwa terdapat pengaruh $E$ learning berbantuan google classroom terhadap kemampuan pemecahan masalah matematis. Berdasarkan hasil tersebut pendidik perlu mengembangkan pembelajaran E-learning untuk meningkatkan kemampuan pemecahan masalah matematis peserta didik, serta pendidik dipandang perlu memberikan soal-soal latihan kemampuan pemecahan masalah matematis untuk membiasakan peserta didik dalam menyelesaikankan soal kemampuan pemecahan masalah matematis. Sebagai peneliti selanjutnya, dihapakan para peneliti lebih memperhatikan faktor-faktor yang mempengaruhi rendahnya kemampuan pemecahan masalah matematis peserta didik.

\section{UCAPAN TERIMA KASIH}

Terima kasih saya ucapkan kepada ibu Anisa Fitri, S.Pd., selaku wali kelas VII SMP Al-Huda Jati Agung yang telah berkenan memberikan izin untuk melakukan penelitian, serta kepada seluruh guru-guru SMP Al-Huda Jati Agung. Terima kasih kepada dosen pembimbing Bapak Iip Sugiharta, M.SI dan Ibu Farida, S.Kom., MMSI.

\section{REFERENSI}

Aji, W., \& Fatma, D. (2020). Dampak Covid-19 Terhadap Implementasi Pembelajaran Daring Di Sekolah Dasar. Edukatif Jurnal Ilmu Pendidikan, 2(1), 55-61.

Al-Ihwanah, A.-I. (2016). Implementasi E-Learning Dalam Kegiatan Pembelajaran Pgmi Iain Sulthan Thaha Saifuddin Jambi. Cakrawala: Jurnal Studi Islam, 11(1), 76-91. https://doi.org/10.31603/cakrawala.v11i1.102

Aldiab, A., Chowdhury, H., Kootsookos, A., \& Alam, F. (2017). Prospect of eLearning in Higher Education Sectors of Saudi Arabia: A Review. Energy Procedia. https://doi.org/10.1016/j.egypro.2017.03.187

Ambara, M. P. (2020). Pengembangan Sistem Informasi E-Learning Mendukung Proses Pembelajaran Jarak Jauh. Jurnal Ilmiah Pendidikan Citra Bakti, 7(2), 137-148. https://doi.org/10.38048/jipcb.v7i2.95

Dian, H., Hascaryo, \& Barokah. (2020). Pendidikan Dalam Masa Pandemi Covid-19'. Jurnal Sinestesia, $10(01)$. 
Hadi, S., \& Radiyatul, R. (2014). Metode Pemecahan Masalah Menurut Polya untuk Mengembangkan Kemampuan Siswa dalam Pemecahan Masalah Matematis di Sekolah Menengah Pertama. EDU-MAT: Jurnal Pendidikan Matematika, 2(1), 53-61. https://doi.org/10.20527/edumat.v2i1.603

Hubers, M. D., D.Endedijk, M., \& Van Veen, K. (2020). Effective characteristics of professional development programs for science and technology education. Professional Development in Education. https://doi.org/10.1080/19415257.2020.1752289

Kertayasa, K. (2015). Indonesia PISA center, WNA: Mathematic web for PISA. Diakses Di Http://Www. Indonesiapisacenter. Com/2014/03/Tentangwebsite. Html.

Mailizar, Almanthari, A., Maulina, S., \& Bruce, S. (2020). Secondary school mathematics teachers' views on e-learning implementation barriers during the COVID-19 pandemic: The case of Indonesia. Eurasia Journal of Mathematics, Science and Technology Education, 16(7). https://doi.org/10.29333/EJMSTE/8240

Murdiana, I. N. (2015). Pembelajaran Pemecahan Masalah dalam Pembelajaran Matematika. Pendidikan Matematika, 4(1), 1-11.

Onyema, E. M., Obafemi, F., Sen, S., \& Sharma, A. (2020). Impact of Coronavirus Pandemic on Education. Journal of Education and Practice, May. https://doi.org/10.7176/jep/11-13-12

Pappas, C. (2015). Google Classroom Review: 16 Pros And Cons Of Using Google Classroom In eLearning. ELearning Industry.

Permata, L. D., Kusmayadi, T. A., \& Fitriana, L. (2018). Mathematical problem solving skills analysis about word problems of linear program using IDEAL problem solver. Journal of Physics: Conference Series, 1108(1). https://doi.org/10.1088/1742-6596/1108/1/012025

Ratheeswari, K. (2018). Information Communication Technology in Education. Journal of Applied and Advanced Research. https://doi.org/10.21839/jaar.2018.v3is1.169

Sahrudin, A. (2014). Implementasi Strategi Pembelajaran Discovery untuk Meningkatkan Kemampuan Pemecahan Masalah Matematis dan Motivasi Belajar Siswa SMA. Jurnal Pendidikan Unsika, 2(1), $1-12$.

Santos, M. L. K. P., Belecina, R. R., \& Diaz, R. V. (2015). Mathematical Modeling: Effects on Problem Solving Performance and Math Anxiety of Students. International Letters of Social and Humanistic Sciences, 65(2013), 103-115. https://doi.org/10.18052/www.scipress.com/ilshs.65.103

Surani, D. (2019). Studi Literatur: Peran Teknologi Pendidikan dalam Pendidikan 4.0. Prosiding Seminar Nasional Pendidikan FKIP, 2(1), 456-469.

Zhang, F., Wang, Y., \& Liu, W. (n.d.). Science and Technology Resource Allocation, Spatial Association, and Regional Innovation. https://doi.org/10.3390/su12020694. 